\title{
Effect of Cellulase and Lactic Acid Bacteria on Fermentation Quality and Chemical Composition of Wheat Straw Silage
}

\author{
Kuikui Ni ${ }^{1}$, Yanping Wang1, Huili Pang1 ${ }^{*}$, Yimin Cai ${ }^{*}$ \\ ${ }^{1}$ Henan Provincial Key Laboratory of Ion Beam Bio-Engineering, Zhengzhou University, Zhengzhou, \\ China \\ ${ }^{2}$ Animal Physiology and Nutrition Division, National Institute of Livestock and Grassland Science, \\ Tsukuba, Japan \\ Email: *pang@zzu.edu.cn, ${ }^{*}$ cai@affrc.go.jp
}

Received 16 April 2014; revised 17 May 2014; accepted 3 June 2014

Copyright (C) 2014 by authors and Scientific Research Publishing Inc.

This work is licensed under the Creative Commons Attribution International License (CC BY).

http://creativecommons.org/licenses/by/4.0/

(c) (i) Open Access

\section{Abstract}

The object of this study was to determine the effect of cellulase and lactic acid bacteria (LAB) on fermentation quality and chemical composition of wheat straw silage. Silages were prepared using a small-scale fermentation system and the moisture level was adjusted to $60 \%$ of fresh matter (FM) with deionized water. Treatments were designed as: control silage without additives, LAB inoculant Lactobacillus casei Z3-1 (1.0 $\times 10^{6} \mathrm{cfu} \cdot \mathrm{g}^{-1} \mathrm{of}$ FM), commercial inoculant L. plantarum FG 1 $\left(1.0 \times 10^{6} \mathrm{cfu}^{-\mathrm{g}^{-1}}\right.$ of FM), Z3-1 + cellulase and FG 1 + cellulase. The neutral detergent fiber (NDF), acid detergent fiber (ADF) and crude protein (CP) contents of the wheat straw prior to ensiling

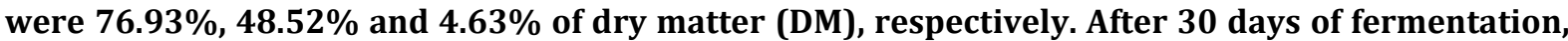
the silages treated with LAB and LAB + cellulase had a lower $(P<0.05) \mathrm{pH}$ and higher $(P<0.05)$ lactic acid content than the control, and the coliform bacteria, yeast and mold were inhibited at the early stage of fermentation. Besides, silages treated with cellulase had lower $(P<0.05)$ values of ADF and NDF than the control. The results confirmed that the addition of cellulase and LAB contributed to improving the fermentation quality of wheat straw silage.

\section{Keywords}

Cellulase, Chemical Composition, Lactic Acid Bacteria, Silage Fermentation, Wheat Straw

\footnotetext{
${ }^{*}$ Corresponding authors
} 


\section{Introduction}

In China, the annual yield of wheat (Triticum aestivum L.) straw is approximately 115.4 million tons [1]. However, about $50 \%$ of this abundant crop by-product is deserted directly in the field or burned for cooking, which cause seriously environmental problems [2]. With the rapid development of animal husbandry, feed shortage has become a limiting factor for livestock production [3]. Therefore, it is necessary to develop silage preparation technique to effectively use these local available feed resources for livestock production in China.

Ensilage has long been used to preserve forage crops for livestock. During fermentation process, the epiphytic lactic acid bacteria (LAB) on forage crops utilizes water-soluble carbohydrate (WSC) to produce lactic acid, the primary acid responsible for decreasing the $\mathrm{pH}$ in silage [4]-[6]. Silage additives have also been used to obtain high-quality silage, and inoculants and cellulase are the most popular additives on silage [4]. LAB inoculants applied to forage at ensiling promote homofermentation of major WSC transfer to lactic acid, which causes a rapid $\mathrm{pH}$ decline [7]. Wheat straw is mainly composed of cellulose, hemicellulose and lignin; hence, its low digestibility prevents the use in feedlots. The addition of cellulase to silage can partially degrade fiber to fermentable WSC used by LAB [8]. The mixtures of inoculants and cellulase had also been used to improve the fermentation quality of silage.

In the present study, we aimed to examine the effect of $\mathrm{LAB}$ and cellulose on the fermentation quality and chemical composition of wheat straw silage by using a small-scale fermentation system.

\section{Materials and Methods}

\subsection{Materials and Silage Preparation}

The wheat (cultivar: Yumai 19) straw was collected from a local farmland (Zhongmou County, Henan Province, China) on June 4, 2012. Deionized water was sprayed to the wheat straw and the final moisture level was approximately $60 \%$ of the fresh wheat straw. A commercial cellulase made from Trichoderma reesei (Heilongjiang Zhaodong Enzyme Product Co. Ltd, Zhaodong, China), and two selected strains: Z3-1 (Lactobacillus (L.) casei, Zhengzhou University, Zhengzhou, China), isolated from corn and FG 1 (L. plantarum) from a commercial inoculant (Chikuso-1, Snow Brand Seed Co. Ltd., Sapporo, Japan), were used as additives. Experimental treatments included control silage without additives, wheat straw + cellulase, wheat straw + Z3-1, wheat straw + FG 1, wheat straw + cellulase + Z3-1 and wheat straw + cellulase + FG 1 silages.

The lactobacilli de Man, Rogosa, Sharpe (MRS) broth inoculated with strains Z3-1 and FG1 was incubated overnight and the inoculum volume of LAB was $1 \mathrm{ml}$ of suspension per kilogram of FM. The numbers of inoculated LAB Z3-1 and FG 1 were both $1.0 \times 10^{6}$ colony-forming units per (cfu) g of FM, respectively, while the added dosage of cellulase was $1.0 \mathrm{~g} \cdot \mathrm{kg}^{-1}$ of the fresh wheat straw. Silages were prepared using a small scale system of silage fermentation, approximately $100 \mathrm{~g}$ portions of forge material chopped into about $20-\mathrm{mm}$ length and packed into plastic bags. The bags were sealed with a vacuum sealer. The plastic bags were stored at room temperature and ten bags were used per treatment.

\subsection{Morphological, Physiological and Biochemical Tests}

Gram-staining response of LAB was examined after $24 \mathrm{~h}$ of incubation on MRS agar. Catalase activity and gas production from glucose were determined using the methods of Cai et al. [3]. Growth at different temperatures was observed in MRS broth after incubation at $5^{\circ} \mathrm{C}$ and $10^{\circ} \mathrm{C}$ for 10 days, and at $45^{\circ} \mathrm{C}$ and $50^{\circ} \mathrm{C}$ for 7 days. Growth at $\mathrm{pH}$ 3.0, 3.5, 4.0, 4.5, 5.0 and 8.0 was observed in MRS broth after incubation at $30^{\circ} \mathrm{C}$ for 7 days. Salt tolerance of LAB was tested in MRS broth containing 3.0\% and 6.5\% $\mathrm{NaCl}$.

\subsection{Microbiological Analysis}

One bag per treatment was opened on day 3, 5, and 10, and 3 bags per treatment were opened in the 30th day, respectively. The wheat straw sample $(10 \mathrm{~g})$ was blended with $90 \mathrm{ml}$ of sterilized water, and serially diluted from $10^{-1}$ to $10^{-5}$ in sterilized water. The number of LAB was measured by plate count on MRS agar incubated at $30^{\circ} \mathrm{C}$ for $48 \mathrm{~h}$ under anaerobic conditions (DG 250/min MACS, Don Whitley Science, England). Coliform bacteria were counted on blue light broth agar (Nissui Ltd., Tokyo, Japan), incubated at $30^{\circ} \mathrm{C}$ for $48 \mathrm{~h}$. Mold and 
yeast were counted on potato dextrose agar (Nissui), incubated at $30^{\circ} \mathrm{C}$ for $24 \mathrm{~h}$, and yeast were distinguished from mold and other bacteria by colony appearance and the observation of cell morphology. Bacilli and aerobic bacteria were counted on nutrient agar (Nissui), incubated at $30^{\circ} \mathrm{C}$ for $24 \mathrm{~h}$ under aerobic conditions. Colonies were counted as viable numbers of microorganisms in $\mathrm{cfu} \cdot \mathrm{g}^{-1}$ of fresh matter.

\subsection{Chemical and Statistical Analysis}

After $30 \mathrm{~d}$ of storage, three bags per treatment were opened for analyzing the chemical composition and fermentation quality. The wheat straw silage samples were dried in a forced-air oven at $65^{\circ} \mathrm{C}$ for $48 \mathrm{~h}$ and ground to pass a 1-mm screen with a Wiley mill (ZM200, Retsch GmbH, Germany). Dry matter (DM), crude protein (CP), ether extract (EE) and organic matter (OM) were analyzed according to AOAC Methods 934.01, 976.05, 920.39 and 942.05, respectively [9]. The crude fiber was analyzed by the methods of Soest et al. [10]. Wet silage (10 g) was homogenized with $90 \mathrm{ml}$ sterilized distilled water. The $\mathrm{pH}$ was measured with a glass electrode $\mathrm{pH}$ meter ( $\mathrm{pH}$ 213, HANNA, Italy), and ammonia-N was determined by steam distillation of the filtrates. The organic acid contents were measured by HPLC (1200 series, Agilent, American) according to the methods described by Cai et al. [4].

The variance analysis and multiple comparisons of data were performed by the GLM procedures of SAS (SAS Institute Inc., Cary, NC, US).

\section{Results}

\subsection{Characteristics of LAB Used in This Experiment}

Morphological, physiological and biochemical properties of LAB used in this experiment are shown in Table 1 , both of the isolated strains Z3-1 and FG 1 were Gram-positive, catalase-negative, homofermentative LAB and could not grow at temperatures of $5^{\circ} \mathrm{C}, 10^{\circ} \mathrm{C}$ and $50^{\circ} \mathrm{C}$. The strain Z3-1 could grow at the salinity of $6.5 \%$ and pH 3.0, while FG 1 could not.

\subsection{Chemical Composition of the Wheat Straw}

The chemical composition of the wheat straw prior to ensiling is shown in Table 2. The DM and OM contents of the wheat straw were $91.61 \%$ and $92.42 \%$ on DM basis, acid detergent fiber (ADF) and neutral detergent fiber (NDF) contents were $48.5 \%$ and $76.9 \%$ on DM basis, respectively. However, contents of CP and EE were relatively low ( $4.63 \%$ and $0.49 \%$ of DM, respectively).

\subsection{Changes in pH and the Microbiological Composition during Silage Fermentation}

Changes in $\mathrm{pH}$ and the microbiological composition during silage fermentation are shown in Table 3 . All the $\mathrm{pH}$ values of silages declined sharply after 3 days of fermentation, but at the day 30, the values of LAB (Z3-1 and of FG 1)- and cellulase + LAB-treated silages decreased to near 4.0, while the control and the cellulase-treated silages were 5.02 and 4.87, respectively. Before ensiling, $10^{3}-10^{4}\left(\mathrm{cfu} \cdot \mathrm{g}^{-1}\right.$ of FM) LAB and mold and $10^{5}$ coliform bacteria, aerobic bacteria and yeast were found in the fresh wheat straw. During the first 3 days of fermentation, numbers of LAB increased rapidly and reached to $10^{8}-10^{9} \mathrm{cfu} \cdot \mathrm{g}^{-1}$ of FM in all silages; at the day 5 fermentation, they remained at this high level, however, after 30 days fermentation, LAB in these silages decreased to $10^{4}-10^{6} \mathrm{cfu} \cdot \mathrm{g}^{-1}$ of FM. Mold and coliform bacteria were not detected in almost all silages after 3 days of fermentation. At the 30 days, the numbers of aerobic bacteria decreased to $10^{3}-10^{4} \mathrm{cfu} \cdot \mathrm{g}^{-1} \mathrm{of} \mathrm{FM}$. Yeast were not detected in all the silages after 30 days of fermentation, except the control and cellulase-treated silages ranging from $10^{4}$ to $10^{5} \mathrm{cfu} \cdot \mathrm{g}^{-1}$ of $\mathrm{FM}$.

\subsection{Chemical Composition and Fermentation Quality of Wheat Straw Silages Treated with LAB and Cellulase after 30 Days of Fermentation}

The chemical composition and fermentation quality of wheat straw silages treated with LAB and cellulase after 30 days of fermentation are shown in Table 4 and Table 5. The OM and EE contents did not differ among these six treatments. The CP contents of the LAB- and cellulase + LAB-treated silages were higher than control and 
Table 1. Morphological, physiological and biochemical properties of LAB used in this experiment.

\begin{tabular}{|c|c|c|}
\hline Characteristics & Z3-1 & FG 1 \\
\hline Source & Rice silage & A commercial inoculation \\
\hline Species & Lactobacillus casei & Lactobacillus plantarum \\
\hline Shape & Rod & Rod \\
\hline Gram stain & + & + \\
\hline Gas from glucose & - & - \\
\hline Catalase & - & - \\
\hline Fermentation type & Homo & Homo \\
\hline \multicolumn{3}{|l|}{ Growth at temperature } \\
\hline $5^{\circ} \mathrm{C}$ & - & - \\
\hline $10^{\circ} \mathrm{C}$ & - & - \\
\hline $15^{\circ} \mathrm{C}$ & $\mathrm{w}$ & $\mathrm{w}$ \\
\hline $45^{\circ} \mathrm{C}$ & + & + \\
\hline $50^{\circ} \mathrm{C}$ & - & - \\
\hline \multicolumn{3}{|l|}{ Growth at $\mathrm{pH}$} \\
\hline 3.0 & + & - \\
\hline 3.5 & + & + \\
\hline 4.0 & + & + \\
\hline 5.0 & + & + \\
\hline 6.0 & + & + \\
\hline 8.0 & + & + \\
\hline \multicolumn{3}{|l|}{ Growth in $\mathrm{NaCl}(\%)$} \\
\hline 3.0 & + & + \\
\hline 6.5 & + & - \\
\hline
\end{tabular}

+: positive; -: negative; w: weakly positive.

Table 2. Chemical composition of wheat straw prior to ensiling.

\begin{tabular}{cc}
\hline Item & Wheat straw \\
\hline DM, \% & $91.61 \pm 0.32$ \\
OM, \% of DM & $92.42 \pm 0.54$ \\
CP, \% of DM & $4.63 \pm 0.22$ \\
EE, \% of DM & $0.49 \pm 0.03$ \\
ADF, \% of DM & $48.52 \pm 1.07$ \\
NDF, \% of DM & $76.93 \pm 1.22$ \\
\hline
\end{tabular}

DM: dry matter; OM: organic matter; EE: ether extract; CP: crude protein; NDF: neutral detergent fiber; ADF: acid detergent fiber.

cellulase-treated silages $(P<0.05)$. The ADF and NDF contents of the cellulase-treated silages were lower than control $(P<0.05)$.

The $\mathrm{pH}$ values of the silages treated with cellulase and LAB were lower than that of the control; the lowest $\mathrm{pH}$ value was found in the LAB- and LAB + cellulase-treated silages, nearly reaching to 4.0. The lactic acid content was highest $(P<0.05)$ in the silages treated with cellulase $+Z 3-1$, increasing to $3.02 \%$ of FM, but the 
Table 3. Changes in counts of viable microorganisms of wheat straw silages during fermentation process.

\begin{tabular}{|c|c|c|c|c|c|c|c|}
\hline \multirow{2}{*}{ Item } & \multirow{2}{*}{ Ensiling days } & \multirow{2}{*}{$\mathrm{pH}$} & \multicolumn{5}{|c|}{ Microorganism (cfu/g of fresh matter) } \\
\hline & & & $\mathrm{LAB}$ & Coliform bacteria & Aerobic bacteria & Mold & Yeast \\
\hline \multirow[t]{5}{*}{ Control } & 0 & 6.18 & $1.0 \times 10^{3}$ & $1.0 \times 10^{5}$ & $2.8 \times 10^{5}$ & $2.3 \times 10^{4}$ & $1.5 \times 10^{5}$ \\
\hline & 3 & 5.20 & $3.0 \times 10^{8}$ & $1.5 \times 10^{8}$ & $1.0 \times 10^{8}$ & ND & $2.5 \times 10^{8}$ \\
\hline & 5 & 5.26 & $2.5 \times 10^{8}$ & $2.0 \times 10^{6}$ & $4.5 \times 10^{6}$ & ND & $1.5 \times 10^{6}$ \\
\hline & 10 & 4.96 & $3.5 \times 10^{5}$ & $1.8 \times 10^{5}$ & $4.3 \times 10^{5}$ & ND & $2.5 \times 10^{4}$ \\
\hline & 30 & 5.02 & $1.5 \times 10^{5}$ & ND & $3.5 \times 10^{4}$ & ND & $1.5 \times 10^{4}$ \\
\hline \multirow[t]{5}{*}{ WS + cellulase } & 0 & 6.18 & $1.0 \times 10^{3}$ & $1.0 \times 10^{5}$ & $2.8 \times 10^{5}$ & $2.3 \times 10^{4}$ & $1.5 \times 10^{5}$ \\
\hline & 3 & 5.23 & $2.5 \times 10^{8}$ & $4.5 \times 10^{8}$ & $6.0 \times 10^{8}$ & ND & $1.8 \times 10^{8}$ \\
\hline & 5 & 5.13 & $2.6 \times 10^{8}$ & $2.7 \times 10^{7}$ & $5.5 \times 10^{6}$ & ND & $3.8 \times 10^{7}$ \\
\hline & 10 & 5.03 & $2.2 \times 10^{7}$ & $1.2 \times 10^{4}$ & $2.1 \times 10^{6}$ & ND & $1.8 \times 10^{5}$ \\
\hline & 30 & 4.87 & $1.2 \times 10^{6}$ & ND & $4.4 \times 10^{4}$ & ND & $5.0 \times 10^{3}$ \\
\hline \multirow[t]{5}{*}{$\mathrm{WS}+\mathrm{FG} 1$} & 0 & 6.18 & $1.0 \times 10^{3}$ & $1.0 \times 10^{4}$ & $2.8 \times 10^{5}$ & $2.8 \times 10^{5}$ & $2.3 \times 10^{4}$ \\
\hline & 3 & 4.67 & $2.5 \times 10^{8}$ & ND & $2.5 \times 10^{3}$ & ND & $2.4 \times 10^{5}$ \\
\hline & 5 & 4.25 & $2.0 \times 10^{8}$ & ND & $2.2 \times 10^{4}$ & ND & $1.3 \times 10^{4}$ \\
\hline & 10 & 4.16 & $6.6 \times 10^{6}$ & ND & $1.5 \times 10^{3}$ & ND & ND \\
\hline & 30 & 4.09 & $3.2 \times 10^{5}$ & ND & $5.0 \times 10^{3}$ & ND & ND \\
\hline \multirow[t]{5}{*}{ WS + Z3-1 } & 0 & 6.05 & $1.0 \times 10^{3}$ & $1.0 \times 10^{5}$ & $2.8 \times 10^{5}$ & $2.3 \times 10^{4}$ & $1.5 \times 10^{5}$ \\
\hline & 3 & 4.55 & $2.6 \times 10^{9}$ & ND & $5.6 \times 10^{5}$ & ND & $4.3 \times 10^{4}$ \\
\hline & 5 & 4.23 & $6.0 \times 10^{8}$ & ND & $1.2 \times 10^{4}$ & ND & $4.4 \times 10^{4}$ \\
\hline & 10 & 4.15 & $2.3 \times 10^{7}$ & ND & $3.0 \times 10^{4}$ & ND & $2.4 \times 10^{5}$ \\
\hline & 30 & 4.11 & $3.4 \times 10^{4}$ & ND & $5.0 \times 10^{3}$ & ND & ND \\
\hline \multirow[t]{5}{*}{ WS + cellulase + FG 1} & 0 & 6.08 & $1.0 \times 10^{3}$ & $1.0 \times 10^{5}$ & $2.8 \times 10^{5}$ & $2.3 \times 10^{4}$ & $1.5 \times 10^{5}$ \\
\hline & 3 & 4.25 & $3.5 \times 10^{8}$ & ND & $4.3 \times 10^{5}$ & ND & $3.5 \times 10^{5}$ \\
\hline & 5 & 4.27 & $2.5 \times 10^{8}$ & ND & $5.3 \times 10^{4}$ & ND & $8.5 \times 10^{4}$ \\
\hline & 10 & 4.16 & $8.0 \times 10^{7}$ & ND & $4.5 \times 10^{4}$ & ND & ND \\
\hline & 30 & 3.98 & $2.1 \times 10^{4}$ & ND & $6.0 \times 10^{4}$ & ND & ND \\
\hline \multirow[t]{5}{*}{ WS + cellulase + Z3-1 } & 0 & 6.05 & $1.0 \times 10^{3}$ & $1.0 \times 10^{5}$ & $2.8 \times 10^{5}$ & $2.3 \times 10^{4}$ & $1.5 \times 10^{5}$ \\
\hline & 3 & 4.31 & $1.0 \times 10^{9}$ & ND & $2.6 \times 10^{4}$ & ND & $1.0 \times 10^{4}$ \\
\hline & 5 & 4.11 & $6.0 \times 10^{8}$ & ND & $3.0 \times 10^{4}$ & ND & $1.0 \times 10^{4}$ \\
\hline & 10 & 4.07 & $5.0 \times 10^{6}$ & ND & $1.5 \times 10^{4}$ & ND & $5.0 \times 10^{3}$ \\
\hline & 30 & 4.03 & $9.0 \times 10^{4}$ & ND & $1.4 \times 10^{4}$ & ND & ND \\
\hline
\end{tabular}

WS: wheat straw; LAB: lactic acid bactria; ND: not detected.

acetic acid content of the silages treated with Z3-1 inoculant and cellulase did not show significant difference than the control. Propionic acid was not detected in all silages; the Butyric acid contents of all the treated silages, except the cellulase-treated silages, were lower than the control, and ammonia- $\mathrm{N}$ contents of all silages were no more than $0.2 \mathrm{~g} \cdot \mathrm{kg}^{-1}$ of FM. 
Table 4. The chemical composition (\% of DM) of wheat straw silage treated with LAB and cellulose after 30 days of fermentation.

\begin{tabular}{cccccc}
\hline Item & OM & CP & EE & ADF & NDF \\
\hline Control & $92.11 \pm 0.55$ & $4.52 \pm 0.06^{\mathrm{a}}$ & $0.50 \pm 0.09$ & $43.11 \pm 0.76^{\mathrm{a}}$ & $70.64 \pm 0.76^{\mathrm{a}}$ \\
WS + cellulase & $92.09 \pm 0.67$ & $4.53 \pm 0.04^{\mathrm{a}}$ & $0.53 \pm 0.07$ & $41.50 \pm 0.89^{\mathrm{b}}$ & $69.17 \pm 0.04^{\mathrm{b}}$ \\
WS + FG 1 & $91.82 \pm 0.76$ & $4.69 \pm 0.04^{\mathrm{b}}$ & $0.55 \pm 0.03$ & $41.55 \pm 0.71^{\mathrm{b}}$ & $69.31 \pm 0.34^{\mathrm{b}}$ \\
WS + Z3-1 & $91.32 \pm 0.75$ & $4.63 \pm 0.05^{\mathrm{b}}$ & $0.53 \pm 0.07$ & $42.81 \pm 0.43^{\mathrm{a}}$ & $69.42 \pm 0.21^{\mathrm{b}}$ \\
WS + cellulase + FG 1 & $92.28 \pm 0.68$ & $4.64 \pm 0.03^{\mathrm{b}}$ & $0.57 \pm 0.04$ & $40.33 \pm 0.88^{\mathrm{b}}$ & $69.03 \pm 0.65^{\mathrm{b}}$ \\
WS + cellulase + Z3-1 & $92.21 \pm 0.89$ & $4.69 \pm 0.05^{\mathrm{b}}$ & $0.54 \pm 0.02$ & $41.87 \pm 0.61^{\mathrm{b}}$ & $68.88 \pm 0.87^{\mathrm{b}}$ \\
\hline
\end{tabular}

Means in the same column with different superscripts in lowercase letter are statistically significantly different $(P<0.05)$; LAB: lactic acid bacteria; OM: organic matter; CP: crude protein; EE: ether extract; ADF: acid detergent fiber; NDF: neutral detergent fiber.

Table 5. Fermentation quality of wheat straw silage prepared with LAB and cellulase after 30 days of storage.

\begin{tabular}{|c|c|c|c|c|c|c|}
\hline \multirow{2}{*}{ Item } & \multirow{2}{*}{$\mathrm{pH}$} & \multicolumn{4}{|c|}{ Organic acid (\% FM) } & \multirow{2}{*}{$\begin{array}{l}\text { Ammonia-N } \\
\text { (g/kg of FM }\end{array}$} \\
\hline & & Lactic & Acetic & Propionic & n-Butyric & \\
\hline Control & $5.02 \pm 0.12^{\mathrm{a}}$ & $0.93 \pm 0.12^{\mathrm{c}}$ & $0.38 \pm 0.08^{\mathrm{a}}$ & ND & $0.64 \pm 0.04^{\mathrm{a}}$ & $0.18 \pm 0.08$ \\
\hline WS + cellulase & $4.87 \pm 0.08^{\mathrm{b}}$ & $0.91 \pm 0.21^{\mathrm{c}}$ & $0.39 \pm 0.06^{\mathrm{a}}$ & ND & $0.76 \pm 0.21^{\mathrm{a}}$ & $0.11 \pm 0.05$ \\
\hline $\mathrm{WS}+\mathrm{FG} 1$ & $4.09 \pm 0.11^{\mathrm{c}}$ & $2.59 \pm 0.16^{\mathrm{b}}$ & $0.20 \pm 0.12^{\mathrm{b}}$ & ND & $0.28 \pm 0.12^{\mathrm{b}}$ & $0.18 \pm 0.09$ \\
\hline WS + Z3-1 & $4.08 \pm 0.09^{c}$ & $2.55 \pm 0.27^{\mathrm{b}}$ & $0.44 \pm 0.10^{\mathrm{a}}$ & ND & $0.20 \pm 0.24^{\mathrm{b}}$ & $0.12 \pm 0.06$ \\
\hline WS + cellulase + FG 1 & $3.98 \pm 0.13^{\mathrm{c}}$ & $2.77 \pm 0.16^{\mathrm{b}}$ & $0.19 \pm 0.13^{\mathrm{b}}$ & ND & $0.23 \pm 0.13^{\mathrm{b}}$ & $0.16 \pm 0.07$ \\
\hline WS + cellulase + Z3-1 & $4.03 \pm 0.04^{c}$ & $3.02 \pm 0.08^{\mathrm{a}}$ & $0.24 \pm 0.08^{\mathrm{b}}$ & ND & $0.31 \pm 0.13^{\mathrm{b}}$ & $0.07 \pm 0.04$ \\
\hline
\end{tabular}

Means in the same column with different superscripts in lowercase letter are statistically significantly different $(P<0.05)$; FM: fresh matter; ND: not detected.

\section{Discussion}

The moisture content of silage material plays an important role influencing silage fermentation, because moisture is required by LAB for metabolic reactions and has a significant effect on the initial level and transport of oxygen during ensilage process [11]. Zheng et al. [12] reported that ensilage quality improved as the moisture content decreased from $80 \%$ to $60 \%$ for sugar beet pulp silage and from $60 \%$ to $45 \%$ for tomato pomace silage, and storage at below 30\% of FM prevents almost all the microbial activity. However, moisture content of the material used in this study is only approximately $10 \%$ of FM which is much lower than the moisture requirement for high-quality silage (usually beyond 50\% of FM). Therefore, the moisture of the wheat straw was moderated to $60 \%$ of FM by spraying distilled water.

Forages are fermented by a complex consortium of microorganisms, predominantly by LAB which convent WSC into organic acid. As a result, the $\mathrm{pH}$ is reduced and the forages are preserved. Generally, when LAB reaches to at least $10^{5}$ ( $\mathrm{cfu} \cdot \mathrm{g}^{-1}$ of FM), silages can be well preserved [13]. However, as shown in Table 2, LAB values $10^{3}$ ( $\mathrm{cfu} \cdot \mathrm{g}^{-1}$ of FM) present in the fresh wheat straw suggest that certain inoculants should be applied to this silage.

Lactobacilli are the dominant microbial population on forage crops and contribute to the lactic acid fermentation for a longer time than do lactic acid-producing cocci. Usually, L. casei and L. plantarum are found living in association with forage crops and silages [14] [15]. Many studies have shown the advantages of such inoculants [13], such as adding selected lactobacilli to ensilage forages can dominant or outnumber the epiphytic LAB. At the beginning of fermentation, production of lactic acid by homofermentative lactobacilli is preferred to reduce the $\mathrm{pH}$ value, which may inhibit the growth of harmful microorganisms such as mold, coliform bacteria and aerobic bacteria. In the present study, the LAB-treated silages have a relatively low $\mathrm{pH}$ at the earlier stage of fermentation, which inhibit the production of n-butyric acid and Ammonia-N. However, in the later days of fer- 
mentation, the LAB- and LAB + cellulase-treated silages have lower LAB number than the control $(P<0.05)$. The plausible reason is that the lower $\mathrm{pH}$ prevents the growth of LAB its own. More surprise, the treatment with both two LAB inoculants reduces extents of ADF and NDF in a relative larger level compare to the cellulase treatment. Guan et al. [16] indicated that this may because the enzymes secreted by microbial degrading the crude fiber during fermentation process. Therefore, strains Z3-1 and FG 1 could be used as excellent inoculants for ensiling wheat straw.

Moreover, Sun et al. [17] reported the addition of cellulase increased substrate for LAB from NDF degradation, and propagation of LAB could be promoted in the early stage of ensiling, which resulted in a rapid increase in lactic acid and a drop of $\mathrm{pH}$, so inhibiting activity of harmful bacteria and plant enzymes for proteolysis. However, the efficiency of such enzymatic hydrolysis has been shown to depend on various factors as substrate, environmental conditions and biomass physicochemical pretreatments [18]. That may mean in some cases enzymes cannot significantly reduce the NDF and ADF contents and improve the silage quality. For example, Mandebva et al. [19] and Kozelov et al. [20] found that fibrous enzyme had no effect on cell wall concentration of bermuda grass and lucerne silage, respectively. In the present study, the NDF and ADF values decreased significantly $(P<0.05)$ in the cellulase-treated silages compared with the control, indicating that the cellulase addition was effectively in degrading the cell wall carbohydrate. Silage treated by cellulase usually can reduce fiber composition and improve the digestibility, and the present experiment also proves the cellulase treatment silage, while raising the quality of fermented, also reduced the fiber composition and hardness of feed. The similar results were also found by Stokes et al. [21], Shepherd et al. [22] and Sun et al. [3]. However, the CP and lactic acid contents of cellulase-treated silages did not show a significant improvement than control, while the $\mathrm{pH}$ values were higher than cellulase + LAB (Z3-1 and FG 1)-treated silages. We consider the main reason of the high $\mathrm{CP}$ content of the sample is for the breed, because almost all fields in that area were treated with the same fertilizer cultivation. The results may indicate that the most epiphytic LAB present in the fresh wheat straw were heterofermentative, which could not effectively ferment the substrate provided by cellulase degrading the fiber, therefore, resulting in poor silage; in contrast, as described before, the homofermentative LAB Z3-1 and FG 1 inoculants could utilize the substrate sufficiently and improve the fermentation quality well.

The concentrations of butyric acid and $\mathrm{NH}_{3}-\mathrm{N}$ in silages are also important criterions for evaluating silage fermentation quality, and they were usually associated with the activity of clostridia. In this study, addition of cellulase and inoculants can decrease the concentrations of butyric acid and ammonia-N at different extents compared with control. Usually, low digestive rate is one of the important factors of restriction wheat straw as livestock feed. This test using fresh straw as material, treated by lactobacillus and cellulase in the process of silage fermentation, not only improve the fermented quality, but promote the digestibility of wheat straw can be expected. The evaluating of the LAB and cellulase treated wheat straw silage through livestock digest test evaluation will be carried out in our laboratory.

\section{Conclusion}

LAB inoculation, especially the addition together with cellulase, could improve the fermentation quality of wheat straw silage better than only cellulase-treated silages. L. casei Z3-1 has a potential ability to be used as commercial inoculant, and its effectiveness on other crop silages is underway in our laboratory.

\section{Acknowledgements}

This work was supported by Foundation of Henan Science and Technology Committee (Grant No. 132300410054, We thank Snow Brand Seed Co. Ltd. (Sapporo, Japan) for providing the commercial LAB inoculant.

\section{References}

[1] Yang, H.Y., Wang, X.F., Liu, J.B., Gao, L.J., Masaharu, I., Yasuoand, I. and Cui, Z.J. (2006) Effects of Water-Soluble Carbohydrate Content on Silage Fermentation of Wheat Straw. Journal of Bioscience and Bioengineering, 3, 232-237. http://dx.doi.org/10.1263/jbb.101.232

[2] Liu, R.G., Yu, H. and Huang, Y. (2005) Structure and Morphology of Cellulose in Wheat Straw. Cellulose, 12, 25-34. http://dx.doi.org/10.1023/B:CELL.0000049346.28276.95

[3] Sun, Q., Gao, F., Yu, Z., Tao, Y., Zhao, S. and Cai, Y. (2012) Fermentation Quality and Chemical Composition of 
Shrub Silage Treated with lactic Acid Bacteria Inoculants and Cellulase Additives. Animal Science Journal, 83 305309. http://dx.doi.org/10.1111/j.1740-0929.2011.00962.x

[4] Cai, Y., Benno, Y., Ogawa, M., Ohmomo, S., Kumai, S. and Nakase, K. (1998) Influence of Lactobacillus spp. from an Inoculants and of Weissella and Leuconostoc spp. from Forage Crops on SILAGe. Applied and Environmental Microbiology, 64, 2982-2987.

[5] Cai, Y. (1999) Identification and Characterization of Enterococcus Species Isolated from Forage Crops and Their Influence on Silage Fermentation. Journal of Dairy Science, 82, 2466-2471. http://dx.doi.org/10.3168/jds.S0022-0302(99)75498-6

[6] Pang, H., Zhang, M., Qin, G., Tan, Z., Li, Z., Wang, Y. and Cai, Y. (2011) Identification of lactic Acid Bacteria Isolated from Corn Stovers. Animal Science Journal, 82, 642-653. http://dx.doi.org/10.1111/j.1740-0929.2011.00894.x

[7] Zahiroddini, H., Baah, J., Absalom, W. and McAllister, T.A. (2004) Effects of an Inoculant and Hydrolytic Enzymes on Fermentation and Nutritive Value of Whole Crop Barley Silage. Animal Feed Science and Technology, 117, 317330. http://dx.doi.org/10.1016/j.anifeedsci.2004.08.013

[8] Eun, J.S. and Beauchemin, K.A. (2007) Relationship between Enzymic Activities and in Vitro Degradation of Alfalfa Hay and Corn Silage. Animal Feed Science and Technology, 145, 53-67. http://dx.doi.org/10.1016/j.anifeedsci.2007.05.039

[9] AOAC (1990) Official Methods of Analysis. 15th Edition, Association of Official Analytical Chemistry, Arlington.

[10] Van Soest, P.J., Robertson, J.B. and Lewis, B.A. (1991) Methods for Dietary Fiber, Neutral Detergent Fiber, and NonStarch Polysaccharides in Relation to Animal Nutrient. Journal of Dairy Science, 74, 3583-3597. http://dx.doi.org/10.3168/jds.S0022-0302(91)78551-2

[11] Troller, J.A. and Stinson, J.V. (1981) Moisture Requirements for Growth and Metabolite Production by Lactic Acid Bacteria. Applied and Environmental Microbiology, 42, 682-687.

[12] Zheng, Y., Matthew, Y., Hnin A., Cheng, Y., Yu, G., Guo, H., Zhang, R., Vander Gheynst, J. and Jenkins, B.M. (2011) Influence of Moisture on Microbial Activity and Silage Quality during Ensilage and Food Processing Residues. Bioprocess and Biosystems Engineering, 34, 987-995. http://dx.doi.org/10.1007/s00449-011-0549-4

[13] Cai, Y., Benno, Y., Ogawa, M. and Kumai, S. (1999) Effect of Applying Lactic Acid Bacteria Isolated from Forage Crops on Fermentation Characteristics and Aerobic Deterioration of Silage. Journal of Dairy Science, 82, 520-526. http://dx.doi.org/10.3168/jds.S0022-0302(99)75263-X

[14] McDonald, P., Hendersonand, N. and Heron, S. (1991) The Biochemistry of Silage. 2nd Edition, Chalcombe Publication, Marlow.

[15] Muck, R.E. (1989) Initial Bacterial Numbers on Lucerne Prior to Ensiling. Grass Forage Science, 44, 19-25. http://dx.doi.org/10.1111/j.1365-2494.1989.tb01905.x

[16] Guan, W.T., Ashbell, G., Hen, Y. and Weinberg, Z.G. (2002) The Effect of Microbial Inoculants Applied at Ensiling on Sorghum Silage Characteristics and Aerobic Stability. Agricultural Sciences in China, 1, 1174-1179.

[17] Sun, Z., Liu, S., Tayo, G., Tang, S., Lin, B., He, Z., Hang, X., Zhou, Z. and Wang, M. (2009) Effects of Cellulase or Lactic Acid Bacteria on Silage Fermentation and in Vitro Gas Production of Several Morphological Fractions of Maize stover. Animal Feed Science and Technology, 152, 219-231. http://dx.doi.org/10.1016/j.anifeedsci.2009.04.013

[18] Cheng, C.L., Lo, Y.C., Lee, K.S., Lee, D.J., Lin, C.Y. and Chang, J.S. (2011) Biohydrogen Production from Lignocellulosic Feedstock. Bioresource Technology, 102, 8514-8523. http://dx.doi.org/10.1016/j.biortech.2011.04.059

[19] Mandebvu, P., West, J.W., Froetschel, M.A., Hatfield, R.D., Gates, R.N. and Hill, G.M. (1999) Effect of Enzyme or Microbial Treatments of Bermuda-Grass Forages before Ensiling on Cell Wall Composition, End Products of Silage Fermentation and in Situ Digestion Kinetics. Animal Feed Science and Technology, 77, 317-329. http://dx.doi.org/10.1016/S0377-8401(98)00247-8

[20] Kozelov, L.K., Lliev, F., Hristov, A.N., Zaman, S. and McAllister, T.A. (2008) Effect of Fibrolytic Enzyme and an Inoculation in Vitro Degradability and Gas Production of Low-Dry Matter Alfalfa Silage. Journal of the Science of Food and Agriculture, 88, 2568-2575. http://dx.doi.org/10.1002/jsfa.3393

[21] Stokes, M.R. and Chen, J. (1994) Effects of an Enzyme-Inoculant Mixture on the Course of Fermentation of Corn Silage. Journal of Daily Science, 77, 3401-3409. http://dx.doi.org/10.3168/jds.S0022-0302(94)77282-9

[22] Shepherd, A.C. and Kung Jr., L. (1996) Effects of an Enzyme Additive on Composition of Corn Silage Ensiled at Various Stages of Maturity. Journal of Dairy Science, 79, 1767-1773. http://dx.doi.org/10.3168/jds.S0022-0302(96)76544-X 